Multifunctional microsphere formulation of fluorescent magnetic properties for drug delivery system

Eny Kusrini, Riesna Prassanti, Dwi Marta Nurjaya, and Cindy Gunawan

Citation: AIP Conference Proceedings 1817, 030011 (2017); doi: 10.1063/1.4976780

View online: http://dx.doi.org/10.1063/1.4976780

View Table of Contents: http://aip.scitation.org/toc/apc/1817/1

Published by the American Institute of Physics 


\title{
Multifunctional Microsphere Formulation of Fluorescent Magnetic Properties for Drug Delivery System
}

\author{
Eny Kusrini ${ }^{1}$ a) , Riesna Prassanti ${ }^{1}$, Dwi Marta Nurjaya ${ }^{2}$, and Cindy Gunawan ${ }^{3}$ \\ ${ }^{I}$ Department of Chemical Engineering, Faculty of Engineering, Universitas Indonesia, \\ Kampus Baru UI, 16424 Depok, Indonesia \\ ${ }^{2}$ Department of Metallurgical and Materials Engineering, Faculty of Engineering, Universitas Indonesia, Kampus \\ Baru UI, 16424 Depok, Indonesia \\ ${ }^{3}$ ithree Institute, University of Technology Sydney, Sydney, NSW 2007, Australia \\ a) Corresponding author: ekusrini@che.ui.ac.id
}

\begin{abstract}
The microsphere formulations of Chit/TPP/Sm/ $/ \mathrm{Fe}_{3} \mathrm{O}_{4} / \mathrm{Rn}$ were prepared by an ionic gelation technique, where Chit $=$ chitosan, $\mathrm{TPP}=$ tripolyphosphate, $\mathrm{Sm}=$ samarium and $\mathrm{Rn}=$ ranitidine. Optimum of microsphere formulation exhibit magnetic and fluorescent properties with adsorption efficiency of $\sim 92 \%$ was obtained for Chit $/ \mathrm{TPP} / \mathrm{Sm} / \mathrm{Fe}_{3} \mathrm{O}_{4} / \mathrm{Rn}$ with ratio 400:500:50:1:20. Fluorescence intensity of microsphere formulations increased with the cumulative amount release of ranitidine, so that the changing of fluorescence intensity at wavelength of $590 \mathrm{~nm}$ referring to the $\mathrm{Sm}^{3+}$ ion could be used as indicator in DDS. With the demonstration of sustained release from microsphere formulation, it allows to investigate the applications to other drugs.
\end{abstract}

\section{INTRODUCTION}

The fluorescence and magnetic properties of drug carrier composite have been recently reviewed, generally described the biological and biomedicine aplication [1]. This multifunctional materials allow to find and treat disease in the human body [2]. The effective diagnostic ability of the composite may reduce side effect of the drug.

Very few materials can meet for drug delivery system. In order to meet good properties as a drug delivery system (DDS), thus we need to design a composite which is non-toxic and photostability with a good fluorescence labelling. Due to their unique flouresence properties, lanthanide is highly candidate for sensor or labelling to overcome the various problem that associated in the coventional imaging probe or drug delivery carrier [3]. Samarium is one of lanthanide metal ion that possess an orange emission with wavelength at $595 \mathrm{~nm}$. Magnetic $\mathrm{Fe}_{3} \mathrm{O}_{4}$ nanoparticles is superparamagnetic properties. This is very interesting and attractive physicochemical properties and multifunctional surface. This is excellent potential for physiological applications such as targeted drug and gene delivery [4]. We proposed for the simultaneous magnetic $\mathrm{Fe}_{3} \mathrm{O}_{4}$ nanoparticles and fluorescence properties from lanthanide-drug encapsulation with chitosan would result in a controlled and targeted drug delivery system. This is a key role in advancing light-based drug delivery systems, allowing us to construct a new fluorescence and magnetic properties for various bioapplications.

Here, we discuss the multifunctional microsphere formulation of fluorescent-magnetic properties for drug delivery system of Chit/TPP/Sm/ $/ \mathrm{Fe}_{3} \mathrm{O}_{4} / \mathrm{Rn}$ where Chit = chitosan, TPP $=$ tripolyphosphate, $\mathrm{Sm}=$ samarium and $\mathrm{Rn}$ $=$ ranitidine, using an ionic gelation method. Ranitidine used as a drug model due to its abbility to cure gastritis. 


\section{METHODS}

\section{Materials}

Chitosan medical grade powder with deacetylation degree of $90.77 \%$, off white, viscosity of 18 cps, moisture content of $6.61 \%$, ash content of $0.73 \%$, protein content of $60.5 \%$, pH 7-8 was purchased from PT Biotech Surindo (West Java, Indonesia). $\mathrm{Sm}\left(\mathrm{NO}_{3}\right)_{3} \cdot 6 \mathrm{H}_{2} \mathrm{O}$ was purchased from Sigma Aldrich (Wisconsin, USA). $\mathrm{FeCl}_{2} \cdot 4 \mathrm{H}_{2} \mathrm{O}$, $\mathrm{FeCl}_{3} .6 \mathrm{H}_{2} \mathrm{O}$ and acetic acid were purchased from Merck, while for sodium tripolyphosphate was obtained from Brataco.

\section{Synthesis of Magnetic $\mathrm{Fe}_{3} \mathrm{O}_{4}$ Nanoparticles}

To $0.12 \mathrm{M}$ solution of $\mathrm{FeCl}_{2} \cdot 4 \mathrm{H}_{2} \mathrm{O}(50 \mathrm{~mL})$ and $50 \mathrm{~mL}$ of $0.24 \mathrm{M} \mathrm{FeCl}_{3} \cdot 6 \mathrm{H}_{2} \mathrm{O}$ solution was stirred and heated at $70^{\circ} \mathrm{C}$ for $15 \mathrm{~min}$. Then, the mixture solution was poured slowly into $100 \mathrm{~mL}$ of $1 \mathrm{M} \mathrm{NH}_{4} \mathrm{OH}$ solution and keep stirred for $30 \mathrm{~min}$. The solution was filtered, then the precipitate was washed by using distilled water, after that then dried at $70^{\circ} \mathrm{C}$ for $3 \mathrm{~h}$ in conventional oven.

\section{Synthesis of Chitosan-Fe-Ranitidine-Sm}

Chitosan solution was prepared by dissolving chitosan in $50 \mathrm{~mL}$ of $2 \%$ acetic acid solution. Chitosan was varied from 0.5 to $2.5 \mathrm{~g}$. The Sm-ranitidine solution was prepared by dissolving $100 \mathrm{mg}$ of ranitidine in $10 \mathrm{~mL}$ of distilled water, followed by adding $\mathrm{Sm}\left(\mathrm{NO}_{3}\right)_{3} \cdot 6 \mathrm{H}_{2} \mathrm{O}$ were stirred for $30 \mathrm{~min}$. The amount of $\mathrm{Sm}\left(\mathrm{NO}_{3}\right)_{3} \cdot 6 \mathrm{H}_{2} \mathrm{O}$ were varied from 50 to $450 \mathrm{mg}$. Matrices of Chitosan-Fe-Sm-Ranitidine was synthesized by adding a certain amount of $\mathrm{Fe}_{3} \mathrm{O}_{4}$ magnetic nanoparticles and Sm-ranitidine solution into the chitosan solution. Magnetic nanoparticles $\mathrm{Fe}_{3} \mathrm{O}_{4} \mathrm{were}$ varied from 5 to $45 \mathrm{mg}$. Then, the solution mixture was stirred for $5 \mathrm{~min}$ and then transferred to microwave for 10 min. Next, $100 \mathrm{~mL}$ of sodium tripolipospat were put into the beaker in microwave and then stirred for $15 \mathrm{~min}$ to form microsphere. After that, the mixture was filtered and dried at $70^{\circ} \mathrm{C}$ by using an oven for $3 \mathrm{~h}$. The TPP solution concentration was varied from 1 to $5 \%$. The microspheres obtained were dried and crushed with mortar to form the Chitosan-Fe-Sm-Ranitidine matrices. Chitosan-Fe-Sm-Ranitidine matrices were characterized for further applications.

\section{Drug Loading and Drug Release Studies}

Preparation of drug adsorption and release system were prepared in accordance with literature [5]. In drug loading, $50 \mathrm{mg}$ matrices was dissolved in $25 \mathrm{ml}$ of distilled water and then allowed to stand for $24 \mathrm{~h}$. After $24 \mathrm{~h}$, retentate and the filtrate was measured its absorbance by using UV-Vis spectrophotometry. In drug release, $25 \mathrm{mg}$ matrix of ranitidine-chitosan-Fe-Sm was dissolved in $10 \mathrm{~mL}$ of simulation fluids are then stored in an incubator at $37^{\circ} \mathrm{C}$. A sample $(2 \mathrm{~mL})$ from container was taken every for $1 \mathrm{~h}$ and was added $2 \mathrm{~mL}$ of simulation fluids into the new container. Sampling was carried out during for $24 \mathrm{~h}$. For further measurement, the samples was diluted to 10 $\mathrm{mL}$ and then absorbance was recorded by using UV-Vis and spectroflourormeter.

\section{Characterization}

Drug loading and drug release test were determined by using UV-Vis spectrophotometry. Absorbance peak of the ranitidine concentration as model drug in the Ranitidine-Chitosan-Fe-Sm matrices were determined by UV-Vis spectrophotometry. Emission properties of matrices were analyzed by spectroflourometry, Hitachi F-2700. The nanoparticles of $\mathrm{Fe}_{3} \mathrm{O}_{4}$ and their microsphere composites were characterized by XRD, and vibrating sample magnetometer (VSM).

\section{RESULTS AND DISCUSSION}

Multifunctional formulation of magnetic and fluorescence properties based on the chitosan- $\mathrm{Fe}_{3} \mathrm{O}_{4}-\mathrm{Samarium}$ ranitidine for drug delivery systems (DDS) have been investigated. The microsphere formulations of $\mathrm{Chit} / \mathrm{TPP} / \mathrm{Sm} / \mathrm{Fe}_{3} \mathrm{O}_{4} / \mathrm{Rn}$ were prepared by an ionic gelation technique with sodium tripolyphosphate as cross-linking agent, where $\mathrm{Chit}=$ chitosan, $\mathrm{TPP}=$ tripolyphosphate, $\mathrm{Sm}=$ samarium and $\mathrm{Rn}=$ ranitidine. Magnetic nanoparticles $\mathrm{Fe}_{3} \mathrm{O}_{4}$ were characterized by X-Ray diffraction and vibrating sample magnetometer (VSM). X-ray diffraction (XRD) patterns showed that the crystal sizes of $\mathrm{Fe}_{3} \mathrm{O}_{4}$ nanoparticles and its optimum microspheres formulation were 13.24 and $80.59 \mathrm{~nm}$, respectively (see Figs. 1 and 2). The diffraction peaks are suitable for the Miller indices of (220), (311), (400), (440), (511) and (440) at an angles of $2 \theta$ of 30.51, 35.52, 43.14, 53.58, 58.02, and 62.38 ${ }^{\circ}$, respectively, 
which were a typical index of the material structure of cubic spinel $\mathrm{Fe}_{3} \mathrm{O}_{4}$. The average crystal sizes of magnetic $\mathrm{Fe}_{3} \mathrm{O}_{4}$ nanoparticles are 21.25, and $13.24 \mathrm{~nm}$ for ratios $\mathrm{Fe}(\mathrm{II}): \mathrm{Fe}(\mathrm{III})=1: 1$ and $\mathrm{Fe}(\mathrm{II}): \mathrm{Fe}(\mathrm{III})=1: 2$, respectively.
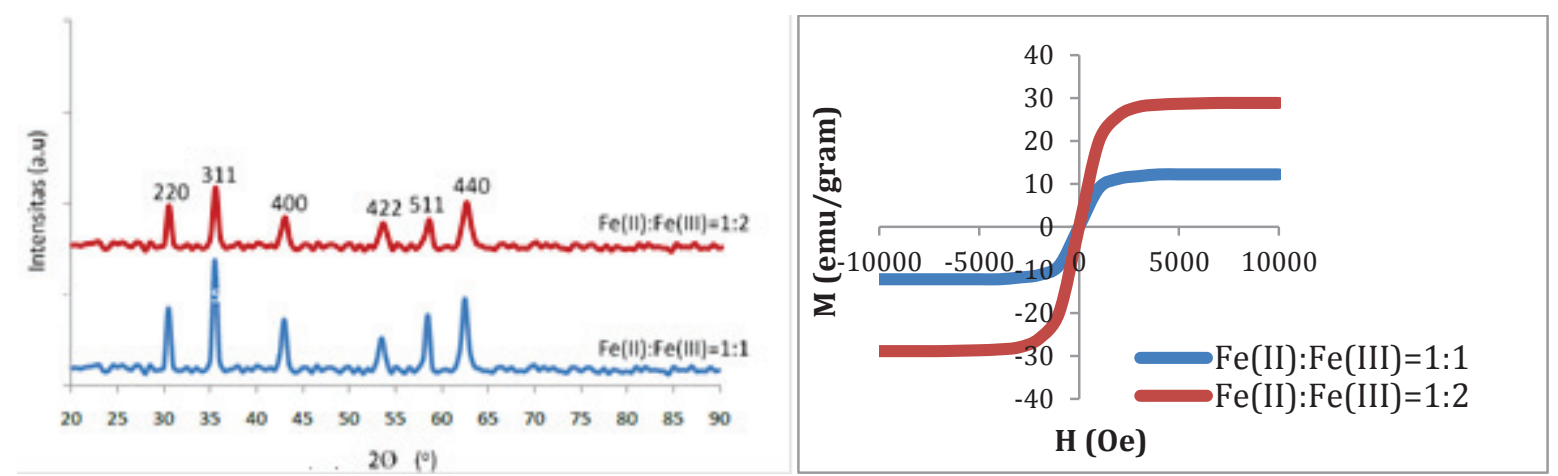

FIGURE 1. (a) XRD characterization result of $\mathrm{Fe}_{3} \mathrm{O}_{4}$, (b) VSM characterization result of $\mathrm{Fe}_{3} \mathrm{O}_{4}$

The XRD spectra of Chit/TPP/Sm/Fe $3 \mathrm{O}_{4} / \mathrm{Rn}$ matrix is shown in Fig. 2(a). The magnetic $\mathrm{Fe}_{3} \mathrm{O}_{4}$ nanoparticles was bonded with Chit/TPP/Sm/ $/ \mathrm{Fe}_{3} \mathrm{O}_{4} / \mathrm{Rn}$ matrices. The diffraction peak at $2 \theta=20^{\circ}$, which is the diffraction peaks of chitosan. The intensity produced by Chitosan-Fe-Sm-Ranitidine composite is lower than pure nanomagnetic nanoparticles $\mathrm{Fe}_{3} \mathrm{O}_{4}$, it indicates that $\mathrm{Fe}_{3} \mathrm{O}_{4}$ has bonded with chitosan thus lowering the intensity value of $\mathrm{Fe}_{3} \mathrm{O}_{4}$. The average crystal size of Chit/TPP/Sm/ $/ \mathrm{Fe}_{3} \mathrm{O}_{4} / \mathrm{Rn}$ matrices is $80.59 \mathrm{~nm}$ that was calculated by using Debye Scherer equation.

The microsphere formulation of Chit/TPP/Sm/ $/ \mathrm{Fe}_{3} \mathrm{O}_{4} / \mathrm{Rn}$ has a maximum magnetization of $2.6 \mathrm{emu} / \mathrm{g}$ (see Figure 2(b)). The maximum magnetization $\mathrm{Fe}_{3} \mathrm{O}_{4}$ pure is $28.9 \mathrm{emu} / \mathrm{g}$. Then $\mathrm{Fe}_{3} \mathrm{O}_{4}$ has weakened because chitosan binds to the matrix. From the characterization results shown that microsphere formulation can be used as conductive matrix for targeted drug carrier. The magnetic $\mathrm{Fe}_{3} \mathrm{O}_{4}$ nanoparticles serves as a sensor or tracer of the drugs in the body.
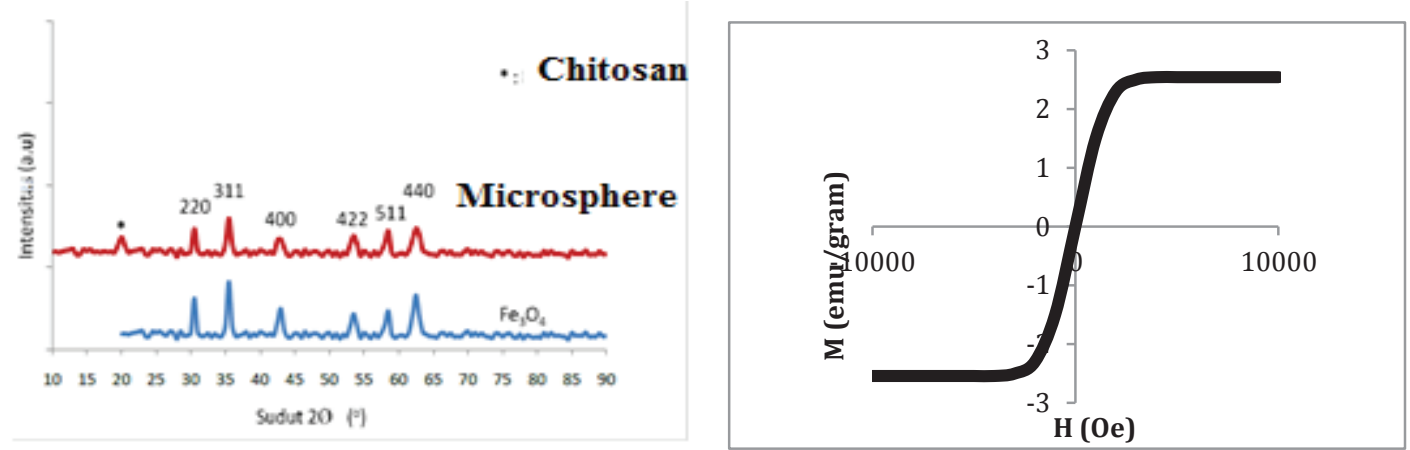

FIGURE 2. Characterization of chitosan-Fe-Sm-Ranitidine for (a) XRD and (b) VSM

In this study, we found that the microsphere formulations was nearly spherical in shape and had a diameter of 20 - $30 \mu \mathrm{m}$ with composition of $\mathrm{Sm}$ and $\mathrm{Fe}$ were about 2.34 and $4.46 \%$, respectively. Magnetic measurement for $\mathrm{Fe}_{3} \mathrm{O}_{4}$ nanoparticles reached $28.9 \mathrm{emu} / \mathrm{g}$ indicated the characteristic of superparamagnetic while the magnetic properties of microsphere formulations of chit $/ \mathrm{TPP} / \mathrm{Sm} / \mathrm{Fe}_{3} \mathrm{O}_{4} / \mathrm{Rn}$ was about $2.6 \mathrm{emu} / \mathrm{g}$, which was decreased compared with the original one $(28.9 \mathrm{emu} / \mathrm{g})$.

The efficiency adsorption of ranitidine on the various of magnetic $\mathrm{Fe}_{3} \mathrm{O}_{4}$ nanoparticles concentrations are almost the same values because of the chemical bonding structure of chitosan-Fe-Sm-ranitidine matrices, the ranitidine as a model drug does not bind to the $\mathrm{Fe}$ ions, thus there is no significant effects on the efficiency adsorption of ranitidine. Therefore the magnetic $\mathrm{Fe}_{3} \mathrm{O}_{4}$ nanoparticles concentration of $100 \mathrm{ppm}$ was selected as the optimum concentration in the formulation of chitosan-Fe-Sm-ranitidine matrices. Optimum of microsphere formulation with adsorption efficiency of $92 \%$ was obtained for Chit/TPP/Sm/ $/ \mathrm{Fe}_{3} \mathrm{O}_{4} / \mathrm{Rn}$ with ratio 400:500:50:1:20.

The relationship between the change in the intensity of flouresence and the release cumulative amount of ranitidine is shown in Fig. 3(a). Fluorescence intensity of microsphere formulations increased with the cumulative 
amount release of ranitidine, so that the changing of fluorescence intensity at wavelength of $590 \mathrm{~nm}$ referring to the $\mathrm{Sm}^{3+}$ ion could be used as indicator in DDS. The $\mathrm{Sm}^{3+}$ ions was bonded with the hydroxyl groups of chitosan that resulted $\mathrm{Sm}^{3+}$ ions fluorescence intensity increases with the ranitidine cumulative amount released from the $\mathrm{Chit} / \mathrm{Sm} / \mathrm{Fe}_{3} \mathrm{O}_{4} / \mathrm{Rn}$ [5]. The existence of samarium in the chitosan matrix has function as a tracer or marker of drug release. The $\mathrm{Sm}^{3+}$ ions also contributes to improve the efficiency of drug loading (see Fig. 3(b)). The release profiles of ranitidine showed that controlled release in sustained release with a diffusion mechanism with the release of up to $40 \%$ on the $8^{\text {th }}$ hour and perfectly separated at the $24^{\text {th }}$ hour were observed.

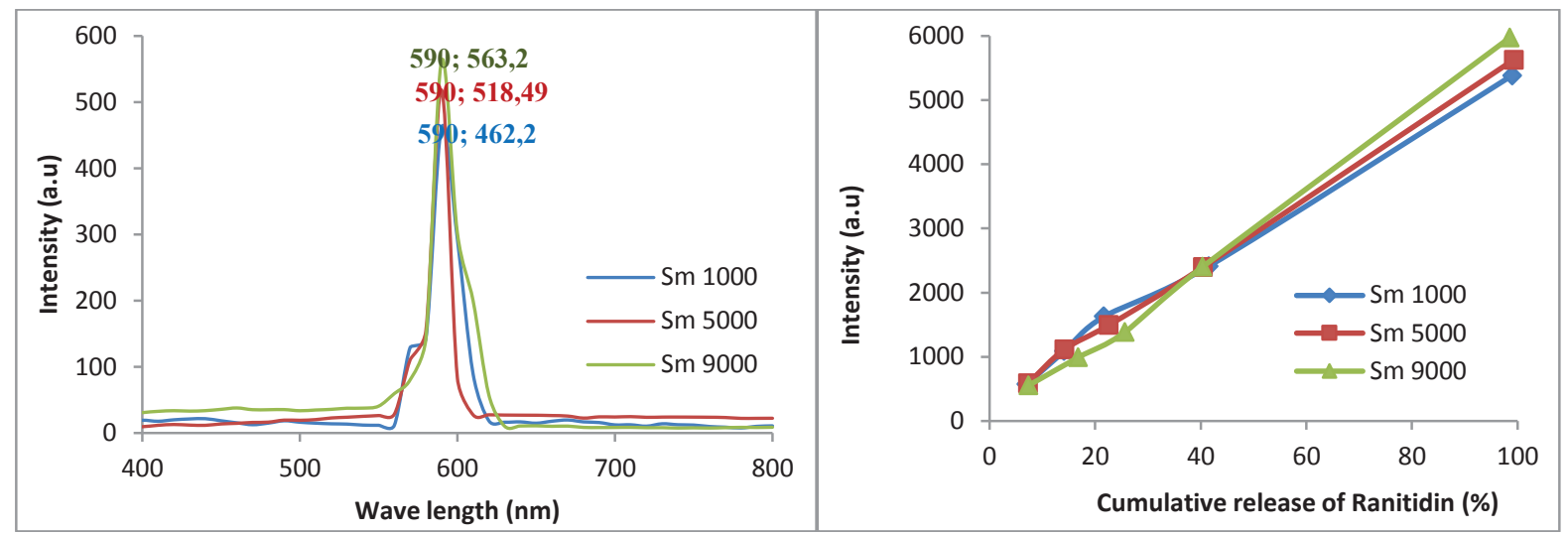

. FIGURE 3. Fluorescence spectra of Chitosan-Fe-Ranitidine-Sm with various Sm concentrations (a), profiles of drug release from Chitosan-Fe-Sm-Ranitidine matrix (b)

\section{CONCLUSION}

In summary, a novel microsphere formulations of Chit/TPP/Sm/ $/ \mathrm{Fe}_{3} \mathrm{O}_{4} / \mathrm{Rn}$ exhibit magnetic and fluorescent properties was developed. The ssustained release from microsphere formulation of Chit/TPP/Sm/ $/ \mathrm{Fe}_{3} \mathrm{O}_{4} / \mathrm{Rn}$ with ratio 400:500:50:1:20, it allows to investigate the applications to other drugs. Furthermore, this is simple and reproducible strategy to synthesize of microsphere formulation for various delivery carrier system.

\section{ACKNOWLEDGEMENTS}

This work was supported by Hibah Riset Unggulan Perguruan Tinggi (Riset Madya), No.2370/H2.R12/HKP.05.00/2013, Universitas Indonesia.

\section{REFERENCES}

1. Shi, J., Tong, L., Ren, X., Li, Q., and Yang, H. Multifuctional Fe ${ }_{3} \mathrm{O}_{4} @ C / Y V O_{4}: D y^{3+}$ Nanopowers: Preparation, Luminescence and Magnetic Properties. Ceramics International. 39 (2013) 6391-6397.

2. Yang, P.P., Quan, Z.W. and Hou, Z.Y. A magnetic, luminescent and mesoporous core- shell structured composite material as drug carrier, Biomaterials. 30 (2009) 4786-4795.

3. Shen, J., Zhao, L., Han, G. Lanthanide-doped upconverting luminescent nanoparticle platforms for optical imaging-guided drug delivery and therapy, Advanced Drug Delivery Reviews 65 (2013) 744-755.

4. Zhou, X., Chen, L., Wang, A., Ma, Y., Zhang, H., Zhu, Y. Multifunctional fluorescent magnetic nanoparticles for lung cancerstem cells research, Colloids and Surfaces B: Biointerfaces 134 (2015) 431-439.

5. Kusrini, E., Arbianti, R., Sofyan, N., Abdullah, M.A.A., Andriani, F. Modification of chitosan by using samarium for potential use in drug delivery system. Spectrochim. Acta Part A. 120 (2014) 77-83. 